\title{
IMPLIKASI PENANAMAN NILAI-NILAI DASAR AGAMA ISLAM TERHADAP PERILAKU ANAK DI TAMAN KANAK-KANAK (TK) “AL-AMIEN" KABUPATEN JEMBER
}

\author{
St. Rodliyah \\ Program Pascasarjana IAIN Jember \\ rodliyahiainjember@gmail.com
}

\begin{abstract}
Religion is the most important and main element in human life, more than that religion is a universal need. Because the rules contained therein contain very high values for buman life and these norms are divine norms that reached humans through divine revelation to the Prophet and his Messenger, which embodied the command (amr) probibition (nahi), and merit (ibahah). This means that if humans understand well, then want to practice as far as the content of the religious teachings, then surely they are a good ummah, in other words they will not harm or offend others and of course will have good morals too. We feel concerned and worried seeing life in this sophisticated and modern era of globalization. Society the higher the intellectual level, but, strangely in terms of behavior (morality) is decreasing. We often see on television and various mass media, there are kindergarten and elementary school children experiencing severe depression due to violence in the family. The impact is that the child chooses to end his life by committing suicide. Therefore, start equipping our children from an early age with education based on religious concepts as a foundation, as strong roots to serve as guidelines so that later our children become buman beings who are able to develop all their potential properly and are ready to face everything. challenge. If we choose the wrong educational institution and provide the foundation for education, it will certainly give birth to a generation that has a mental crisis that will lead to the destruction of the nation.
\end{abstract}

Keywords: Implication, Basic Values of Islam, Child Behavior

\section{Abstrak}

Agama merupakan unsur yang paling penting dan utama dalam kehidupan manusia, lebih dari itu agama merupakan kebutuhan yang universal. Karena kaidah-kaidah yang terkandung di dalamnya 


\section{St. Rodliyah}

mengandung nilai-nilai yang sangat tinggi bagi kehidupan manusia dan kaidah-kaidah tersebut merupakan norma-norma ketuhanan yang sampai kepada manusia melalui wahyu Ilahiyah kepada Nabi dan Rasulnya, yang mewujudkan perintah (amr) larangan (nahi), dan kebolehan (ibahah). Hal ini berarti jika manusia memahami dengan baik, kemudian mau mengamalkan sejauh isi ajaran agama tersebut, maka pastilah mereka ummat yang baik dengan kata lain mereka tidak akan merugikan atau menyinggung perasaan orang lain dan sudah barang tentu akan memiliki moral yang baik juga. Kita merasa prihatin dan khawatir melihat kehidupan di era globalisasi yang serba canggih dan modern ini. Masyarakat semakin tinggi tingkat intelektualnya, Tetapi, anehnya dari segi perilaku (moralitas) semakin menurun. Sering kita menyaksikan di tayangan televisi dan berbagai media massa, ada anak usia taman kanakkanak dan SD mengalami depresi cukup berat akibat kekerasan dalam keluarga. Dampaknya si anak memilih mengakhiri hidupnya dengan cara bunuh diri. Oleh karena itu, mulailah membekali anak-anak kita sejak dini dengan pendidikan yang berlandaskan konsep-konsep agama sebagai fondasi, sebagai akar yang kuat untuk dijadikan pedoman agar kelak anakanak kita menjadi manusia yang mampu mengembangkan seluruh potensi dirinya dengan baik dan siap menghadapi segala tantangan. Apabila kita salah memilih lembaga pendidikan dan salah memberikan landasan pendidikan, maka sudah pasti akan melahirkan generasi yang memiliki krisis mentalitas yang akan mengakibatkan kehancuran bangsa.

\section{Kata Kunci : Implikasi, Nilai Dasar Agama Islam, Perilaku Anak}

\section{Pendahuluan}

Anak merupakan amanah allah SWT., yang dilahirkan dalam keadaan suci dan bersih. Orang tua (bapak dan ibu), dan para pendidik yang akan menentukan kondisi anak selanjutnya. Apakah dia akan menjadi muslimin yang berbakti kepada Allah SWT atau menjadi yang lain. Tugas orang tua sebagai pendidik yang pertama dan utama dalam mendidik anak adalah sangat berat. Karena di dalam keluarga, anak pertama kali berkenalan dengan nilai dan norma. Maka dari itu, tanggungjawab orang tua terhadap anak, khu- 
Vol. 13, No. 2, Oktober 2020

p-ISSN:2086 -0749

e-ISSN:2654-4784

susnya dalam pembentukan perilaku anak sangat besar sekali ${ }^{1}$.

Sebagai amanah, maka menjadi tugas dan kewajiban orang tua untuk merawat, menjaga, serta membesarkan anak dengan penuh cinta dan kasih sayang. Orang tua juga berperan membina, membimbing, mengarahkan, meningkatkan dan mengembangkan seluruh potensinya agar optimal. Potensi atau kecerdasan tidak sekedar intelektual, melainkan juga kecerdasan emosional, spiritual, musik, ruang (spasial), interpersonal, dan sosial. Upaya mengoptimalkan berbagai potensi yang sering disebut kecerdasan jamak (multiple intellegences) itu, dilakukan melalui dunia pendidikan. Bahkan, pendidikan seharusnya dilakukan dari usia dini, sejak "usia emas" (golden age).

1 Tafsir, Ahmad, 1994, Ilmu Pendidikan Dalam Perspektif Islam, Bandung: Rosdakarya, h. 213
Usia emas ini merupakan masa-masa peka, masa anak memiliki "sensitivitas" yang tinggi. Dalam masa ini, tergantung kepada kita sebagai orang tua untuk memberikan pendidikan atau memilihkan pendidikan model apa kepada anak-anak kita. Apakah model pendidikan Barat ? Model pendidikan Islami ? Atau, model pendidikan dengan celupan "warna hitam" atau "warna putih" sehingga hasilnya pun kurang jelas atau samar-samar. Ini semua tergantung kepada kedua orang tuanya $^{2}$

Pendidikan Anak Usia Dini (PAUD) adalah suatu upaya pembinaan yang ditujukan kepada anak sejak lahir sampai dengan usia 6 tahun yang dilakukan melalui pemberian rangsangan pendidikan untuk membantu pertum-

2 (Ima Hikmawati, 2006- www. Pikiran- Rakyat.com.). 


\section{St. Rodliyah}

buhan dan perkembangan jasmani dan rohani agar anak memiliki kesiapan dalam memasuki pendidikan lebih lanjut. Pendidikan Taman Kanak-kanak (TK) merupakan lembaga pendidikan yang pertama dijalani oleh anak di luar pendidikan keluarga yang tentunya merupakan lembaga yang pertama dan utama. Pendidikan keluarga terbaik adalah dengan memberikan teladan kepada anakanak, baik sikap, perilaku serta ucapan sehingga orang tua akan menjadi figur yang dibanggakan. Orang tua harus lebih terbuka dan selektif dalam memilih lembaga pendidikan khususnya TK yang dapat memfasilitasi segala kebutuhan anak-anak, yaitu lembaga pendidikan yang memiliki konsepkonsep Islami yang dapat mengembangkan fitrah anak beragama, mengembangkan wawasan pemahaman, pembiasaan, mengamalkan ibadah atau akhlak ${ }^{3}$.

\footnotetext{
3 Depdiknas, 2003, Kurikulum 2004 Standar Kompetensi Pendidikan anak Usia
}

Artikel ini bertujuan untuk : (1) merumuskan model dan metode pembelajaran yang digunakan dalam penanaman nilai - nilai dasar agama Islam di TK "Al-Amin" Jember, (2) mengetahui materi yang diberikan dalam penanaman nilai-nilai dasar agama Islam di TK "Al-Amin" Jember, dan (3) menganalisis implikasi penanaman nilai-nilai dasar agama Islam terhadap perilaku anak di TK "Al-Amin" Jember baik di rumah maupun di sekolah.

\section{Tinjauan Pustaka}

\section{a. Penanaman Nilai-Nilai \\ Dasar Agama Islam}

Suatu persoalan yang timbul dalam merealisir penanaman nilainilai dasar agama Islam bagi anak itu umumnya berkisar pada: ... apa yang harus diberikan kepada mereka dan cara mana yang harus kita pakai untuk itu, dan sebagainya. Dalam hal ini tentu

Dini: Taman Kanak-Kanak dan Raudhatul Athfal, Jakarta. 
Vol. 13, No. 2, Oktober 2020

p-ISSN:2086 -0749

e-ISSN:2654-4784

saja kita harus menyadari, bahwa mereka itu bukan kita, penghayatan mereka juga tidak sama dengan kita dan kemampuan mereka juga berlainan dengan kemampuan kita. Dengan demikian, menurut Muhammad Tholhah Hasan ${ }^{4}$ bahwa para ulama dan sarjana Islam telah mempunyai pendapat bahwa ajaran agama Islam yang sudah harus kita berikan kepada anakanak tersebut adalah terutama yang berkaitan dengan adabulIslam dan al-ahklaqul fadlilah (kesopanan-kesopanan Islam dan budi yang luhur) sesuai dengan ajaran agama Islam yang dirintis oleh Nabi Muhammad saw.

Usia dini merupakan masa pembentukan yang paling penting, karena sangat menentukan sikap dan perilaku seseorang di

${ }^{4}$ Hasan, M, Tholhah, 2003, Islam Dan Masalab Sumber Daya Manusia, Jakarta: Lantabora Press, h. 14 kemudian hari. Apabila anak usia dini mendapat rangsangan atau pembinaan yang tepat, maka anak tersebut akan dapat tumbuh dan berkembang secara baik serta optimal. Oleh karena itu, suatu hal yang penting bagi pendidik untuk menerapkan pembinaanpembinaan pada anak usia dini berdasarkan keteladanan yang dicontohkan oleh Rasulullah SAW sebabagai berikut:

\section{Pembinaan Aqidah}

Aqidah Islam memiliki enam aspek keimanan yaitu, kepada Allah SWT, kepada para malaikat-Nya, kepada kitab-kitab yang telah diturunkan-Nya, kepada para rasul utusan-Nya, kepada hari akhir, dan kepada ketentuan yang telah dikehendakiNya (qodho' qodar-Nya), apakah itu takdir baik ataupun buruk.

Seluruh aspek keimanan tersebut merupakan hal yang gaib, 


\section{St. Rodliyah}

tidak mampu ditangkap dengan panca indera. Hal ini yang tampaknya sulit dijelaskan pada anak, dengan cara apa bisa ditanamkan enam aspek keimanan pada mereka dan bagaimana anak dapat mengekspresikan keimanan mereka? namun apabila dipelajari proses kehidupan Rasulullah SAW dengan segala yang telah beliau ajarkan, akan diperoleh jawaban dari pertanyaan-pertanyaan tersebut. Ada beberapa pola dasar pembinaan aqidah yaitu :

1) Membacakan Kalimat Tauhid pada Anak

2) Menanamkan Kecintaan Anak Kepada Allah SWT.

3) Menanamkan Kecintaan Anak Pada Rasulullah SAW.

4) Mengajarkan Al-Qur'an Pada Anak ${ }^{5}$.

\section{Pembinaan Syari'ah}

Pembinaan syari'ah diberikan melalui pengenalan hukum yang paling mudah dulu

\footnotetext{
${ }^{5}$ Uhbiyati, Nur, 1998, Imu Pendidikan Islam, Bandung: CV. Pustaka Setia, h. 25
}

yaitu halal (boleh dilakukan) dan haran (tidak boleh dilakukan), dan lain sebagainya. Selanjutnya diberikan pelajaran syari'ah atau fiqh yang berkenaan dengan ibadah, karena beribadah dianggap sebagai penyempurna dari pembinaan aqidah. Selain itu ibadah yang didapat oleh anak akan dapat menambah keyakinan akan kebenaran ajarannya. Semakin tinggi nilai ibadah yang dimiliki, akan semakin tinggi pula keimanannya. Maka bentuk ibadah yang dilakukan anak bisa dikatakan sebagai cerminan atau bukti nyata dari aqidahnya.

Said Ramadhan al-Buthi dalam bukunya Tajribah atTarbiyah al-Islamiyah hlm 40 menjelaskan hubungan antara ibadah dengan pembinaan aqidah anak. Beliau mengatakan: "Agar aqidah anak tertanam kuat di dalam jiwanya, ia harus disiram dengan air ibadah dalam berbagai bentuk dan macamnya, sehingga aqidahnya dapat tumbuh dengan 
Vol. 13, No. 2, Oktober 2020

p-ISSN:2086 -0749

e-ISSN:2654-4784

kukuh, tegar dalam menghadapi terpaan badai dan cobaan kehidupan.

\section{Pembinaan Akhlak}

Pembinaan akhlak pada anak sejak usia dini sangat penting, sebagaimana perkataan Imam Al-Ghazali: "Anak adalah amanat bagi orang tuanya, hatinya yang suci adalah permata yang mahal, kosong dari segala ukuran dan gambaran, anak selalu menerima segala yang diukirkan padanya dan akan cenderung terhadap apa saja yang mempengaruhinya, maka apabila dia dibiasakan untuk melakukan kebaikan niscaya ia akan terbentuk seperti itu dan akan mendapatkan kebahagiaan di dunia dan akhirat, tetapi apabila anak dibiasakan untuk melakukan kejahatan dan ditelantarkan seperti binatangbinatang maka ia akan sengsara dan binasa".
Penanaman akhlak yang baik kepada anak adalah pemberian yang terbaik orang tua kepada anak. Karena dengan akhlak yang baik anak akan mampu berperilaku yang sopan, berbahasa dan bertutur kata yang baik, berpakaian yang sopan, bersikap yang terpuji dan hormat kepada guru, orang tua, orang yang lebih tua, serta mengasihi kepada sesama teman.

\section{Model dan Metode Pembelajaran Dalam Penanaman Nilai-Nilai asar Agama Islam}

Model pembelajaran pada pendidikan TK dilakukan dengan berpedoman pada suatu program kegiatan yang telah disusun sehingga seluruh perilaku dan kemampuan dasar yang ada pada anak dapat dikembangkan dengan sebaik-baiknya.

Menurut 


\section{St. Rodliyah}

Depdiknas ${ }^{6}$ model pembelajaran pada anak TK baik yang berkaitan dengan kurikulum umum maupun keagamaan hendaknya memperhatikan prinsip-prinsip ${ }^{7}$ sebagai berikut :

a. Pembelajaran Berorientasi Pada Perkembangan Anak

b. Pembelajaran Berorientasi Pada Kebutuhan Anak

c. Pembejaran Berorientasi Pada Bermain Sambil Belajar atau Belajar seraya Bermain.

d. Pembelajaran Berorientasi Pada Penggunaan Pendekatan Tematik

e. Pembelajaran Berorientasi Pada kreatif dan Inovatif

f. Pembelajaran berorientasi Pada Lingkungan Kondusif.

g. Pembelajaran Berorientasi Pada Prinsip mengembangkan Kecakapan hidup.

${ }^{6}$ Depdiknas, 2003, Kurikulum 2004 Standar Kompetensi Pendidikan anak Usia Dini, h. 10

7 Http://www.suara pembaharuan.com/ News/2006/05/17/index.html
Metode atau cara merupakan salah satu hal penting yang harus diperhatikan oleh para pendidik dalam proses pendidikan anak, karena metode yang sesuai akan menunjang keberhasilan tujuan pendidikan yang telah ditetapkan. Metode yang diterapkan oleh pendidik itu sangat erat kaitannya dengan kemampuan anak, usia anak serta situasi dan kondisi dimana pendidikan itu berada. Kesalahan atau kekeliruan memilih metode yang digunakan dalam mendidik anak akan berakibat buruk, bahkan akan bisa terjadi kegagalan dalam belajar. Metode-metode yang baik yang bisa diaplikasikan oleh para pendidik pada masa awal pertumbuhan dan perkembangan anak adalah sebagai berikut: (1) keteladanan, (2) pembiasaan, (3) cerita atau dongeng, dan (4) bermain.

\section{Tinjauan Tentang Perilaku}

Anak 
Vol. 13, No. 2, Oktober 2020

p-ISSN:2086 -0749

e-ISSN:2654-4784

Azwar memandang perilaku manusia atau human behavior adalah "sebagai reaksi yang dapat bersifat sederhana maupun bersifat kompleks"8. Dengan demikian yang dimaksud dengan perilaku anak adalah segala perbuatan atau tingkah laku anak yang tampak dalam bereaksi terhadap sesuatu baik terhadap dirinya atau orang lain yang dapat bersifat sederhana maupun bersifat kompleks.

Sebagian besar perilaku manusia (anak) adalah merupakan perilaku yang dibentuk atau perilaku yang dipelajari. Berkaitan dengan hal tersebut maka persoalannya adalah bagaimana caranya membentuk perilaku anak itu agar sesuai dengan yang kita harapkan.
Menurut Walgito perilaku dapat terbentuk melalui tiga $\mathrm{hal}^{9}$ yaitu :

a. Cara pembentukan perilaku dengan konditioning atau kebiasaan. Dengan cara membiasakan diri untuk berperilaku seperti yang diharapkan, akhirnya akan terbentuklah perilaku tersebut. Misalnya dibiasakan bangun pagi kemudian sholat subuh atau berdo'a sebelum dan sesudah makan, mengucapkan terima kasih bila diberi sesuatu oleh orang lain dan sebagainya.

b. Pembentukan perilaku dengan pengertian atau insight. Sebagai contoh datang ke sekolah jangan sampai terlambat karena hal tersebut

${ }^{9}$ Walgito, Bimo, 2003, Psikologi Sosial: suatu Pengantar, Yogyakarta: PT. Remaja Rosdakarya, h. 16 


\section{St. Rodliyah}

dapat mengganggu temanteman yang lain.

c. Pembentukan perilaku dengan menggunakan model atau contoh. Kalau ada pendapat bahwa orang tua itu adalah contoh atau tauladan bagi anak-anaknya, pemimpin sebagai panutan bagi orangorang yang dipimpinnya, itu menunjukkan bahwa kalau kita menjadi orang tua atau pemimpin seharusnya jadilah orang yang benar-benar baik, sehingga mampu menjadi contoh atau model yang baik.

\section{Dalam hal ini Djazuli} mengungkapkan bahwa upaya para pendidik terutama orang tua dalam membentuk perilaku anak yang bercorak agama selain dari siklus kehidupan secara Islami juga diperoleh dari melatih, membiasakan, dan menanamkan nilai-nilai dasar agama yang sesuai dengan dasar mora ${ }^{10}$. Selain itu

${ }^{10}$ Djazuli, 2004, Sosialisai Nilai-Nilai Agama Pada Anak Dalam Keluarga Mus- orang tua dan para pendidik dituntut untuk membantu anak agar dapat membaca perilakunya sendiri. Apakah anak melakukan penyimpangan terhadap nilai-nilai dasar agama atau tidak. Kesadaran ini akan menghindarkan anak dari mengulang kesalahan yang sama, serta dapat mengembangkan terhadap perilaku yang bersesuaian dengan nilai-nilai agama.

Perilaku anak dapat dikelompokkan ke dalam dua hal yaitu sebagai berikut:

a. Perilaku anak di Sekolah

Sekolah adalah lembaga pendidikan yang sangat penting sesudah keluarga. Peran sekolah bagi pembentukan kepribadian dan perilaku anak sangat besar. Sekolah berfungsi untuk membina anak tentang kecerdasan, sikap, minat dan sebagainya dengan gaya dan caranya sendiri sehingga anak menaatinya. Oleh karena itu,

lim, Jurnal, El-Harakah, Wacana Kependidikan, Keagamaan dan Kebudayaan, Malang: UIN, H. 6 
Vol. 13, No. 2, Oktober 2020

p-ISSN:2086 -0749

e-ISSN:2654-4784

dapat dikatakan sekolah

Dalam kenyataannya berpengaruh terhadap jiwa dan perkembangan anak.

Setelah masuk sekolah, anak harus dapat menyesuaikan diri dengan kondisi serta aturan-aturan sekolah yang berlaku dan formulatif. Tidak sedikit anakanak pada awal sekolah menangis karena belum dapat menyesuaikan diri dengan kondisi dan situasi yang baru ${ }^{11}$. Di lingkungan sekolah anak berinteraksi dengan kepala sekolah, guru, beserta bahan-bahan pendidikan dan pengajaran, teman-teman peserta didik lainnya serta pegawai tata usaha. Anak memperoleh pendidikan berupa pembentukan nilai-nilai pengetahuan, keterampilan dan sikap melalui proses pembelajaran.

b. Perilaku Anak di Rumah

11 Ary H, Gunawan, 2000, Sosiologi Pendidikan, Jakarta : PT. Rineka Cipta, h. 49

12 Ary H, Gunawan, 2000, Sosiologi Pendidikan, h. 57 


\section{St. Rodliyah}

pembentukan pembiasaanpembiasaan (habit formations), seperti cara makan, tidur, bangun pagi, gosok gigi, mandi, berpakaian, tata krama, sopan santun, relegi, dan lain sebagainya. Pendidikan informal dalam keluarga akan banyak membantu dalam melakukan dasar pembentukan kepribadian anak khususnya perilaku anak. Misalnya sikap religius, disiplin, lemah lembut atau kasar, rapi atau rajin, penghemat atau pemboros dan sebagainya dapat tumbuh, bersemi dan berkembang senada dan seirama dengan kebiasaannya di rumah.

\section{Metode Penelitian}

Pendekatan penelitian yang digunakan adalah kualitatif, jenisnya deskriptif. . Lokasi penelitian ini adalah di TK "Albaitul Amin' Kabupaten Jember. Penentuan subyek penelitian menggunakan purposive. Subyeknya terdiri dari; Kepala
Sekolah, G, penguururus, Wali Murid, dan Murid. Teknik pengumpulan data menggunakan teknik observasi semi partisipan, wawancara mendalam, dan studi documenter. Anaisisnya datanya menggunakan analisis deskriptif kualitatif dengan model interaktif Milles Huberman dan Saldana, dengan tiga langkah yaitu: kondensasi data, penyajian data, dan verifikasi data/penarikan kesimpulan. Sedangkan keabsahan data menggunakan kridibilitas yang meliputi diskusi teman sejawat dan triangulasi, kemudian dependabilatas, dan konfirmabilitas agar hasil penelitian betul-betul bisa dipertangungjawabkan.

\section{Hasil Penelitian dan Pem-} bahasan

1. Analisa Model dan Metode Pembelajaran Yang Digunakan Dalam Penanaman Nilai - Nilai Dasar Agama Islam di TK "Al-Amin" Jember 
Vol. 13, No. 2, Oktober 2020

p-ISSN:2086 -0749

e-ISSN:2654-4784

Model pembelajaran yang digunakan dalam penanaman nilainilai dasar agama Islam di TK "Al-Amien" Jember, bisa dikatakan beragam sekali sesuai dengan latar pendidikan guru masing-masing, namun semua model yang digunakan masih tetap mengacu pada prinsip-prinsip model pembelajaran anak TK, baik itu yang berkaitan dengan kurikulum umum maupun kurikulum kegamaan. Semua model yang diterapkan oleh para guru selalu berorientasi untuk mengembangkan perilaku dan kemampuan dasar yang ada pada anak sebaik-baiknya dan seoptimal mungkin.

Kegiatan pembelajaran bagi anak harus senantiasa berorientasi pada perkembangan anak dan kebutuhan anak, karena pada masa usia dini (4-6) tahun anak sedang membutuhkan upaya- upaya pendidikan secara maksimal untuk mencapai optimalisasi semua aspek perkembangan baik perkembangan fisik maupun psikhis (intelektual, bahasa, motorik, dan sosio emosional). Anak belajar dengan baik apabila kebutuhan fisiknya terpenuhi serta merasakan aman dan tentram secara psikhologis. Anak belajar melalui interaksi sosial dengan orang dewasa dan anak-anak lainnya, minat dan keingintahuan anak akan memotivasi belajarnya. Pada masa usia ini, orang tua pada khususnya dan guru pada umumnya perlu memberikan perhatian khusus dengan cara memberikan pengalaman yang beragam sehingga memperkuat perkembangannya. Untuk itu seorang guru ketika mengajar juga harus menggunakan model pembelajaran yang berorientasi pada perkembangan anak, 


\section{St. Rodliyah}

kebutuhan anak, bermain sambil belajar atau belajar seraya bermain, kreativitas dan inovatif, lingkungan yang kondusif, mengembangkan kecakapan hidup, dan penggunaan pendekatan tematik. Agar pertumbuhan dan perkembangan anak benar-benar maksinal.

Sedangkan metode pembelajaran yang digunakan oleh para guru TK "Al-Amien" Jember bermacam-macam, semuanya bertujuan untuk mencapai tujuan pendidikan yang telah ditetapkan. Metode pembelajaran sangat erat kaitannya dengan kemampuan anak, usia perkembangan anak, serta situasi dan kondisi lingkungan di mana anak itu bersekolah. Dalam memilih metode pembelajaran guru harus benar-benar mampu memilih metode yang pas dan sesuai dengan karakteristik anak. Karena jika sampai ada kesalahan atau kekeliruan dalam memilih metode tentunya tujuan pembelajaran tidak akan bisa berhasil secara maksimal.

Beberapa metode yang telah diterapkan oleh para guru TK "Al-amien" tidak berbeda jauh dengan metode yang diajarkan dalam mendidik anak usia dini, karena pendidikan TK juga termasuk pendidikan anak usia dini (0-6 tahun) dan pendidikan TK usia 4-6 tahun. Namun ada beberapa tambahan metode yang sengaja dilaksanakan untuk memotivasi dan mengoptimalkan perhatian anak agar konsentrasi dalam belajar. Metode pembelajaran tersebut meliputi; metode keteladanan, pembiasaan, cerita atau dongeng, nasehat, gambar/lukisan, dan bermain serta mainan. Sedangkan metode yang paling mudah diterapkan di pendidikan TK menurut hasil data yang telah peroleh peneliti dari para guru TK adalah metode keteladanan (bil bal), karena dengan metode ini walaupun murid tidak faham apa yang 
dijelaskan oleh ibu guru, jika guru memberi contoh misalnya praktek berwudhu pasti anak-anak akan mengikutinya seperti apa yang dikerjakan oleh ibu guru.

\section{Analisa Materi Yang Diberikan Dalam \\ Penanaman Nilai-Nilai \\ Dasar Agama Islam di TK "Al-amien" Jember.}

Materi pendidikan agama Islam yang diberikan di TK "AlAmien" Jember adalah mengacu pada apa yang dikemukakan oleh Para ulama dan sarjana Islam yang mempunyai pendapat bahwa ajaran agama Islam yang sudah harus kita berikan kepada anakanak tersebut adalah terutama soal-soal adabul Islam dan alakblakul fadlilab (kesopanankesopanan Islam dan budi yang luhur) sesuai dengan ajaran agama Islam yang dirintis oleh Nabi Muhammad saw. Sebab jika sejak kecil anak-anak itu sudah dibiasakan mengamalkan sopan santun dan budi yang luhur, maka jiwa anak tersebut akan merupakan tanah yang subur untuk ditanami benih-benih Islam, dan selanjutnya ajaran-ajaran Islam akan dapat berkembang subur di dalam jiwa anak-anak tersebut.

Penanaman nilai-nilai dasar agama Islam yang diterapkan juga berpedoman pada apa yang dikemukakan oleh Muhyi Hilal Sarhan yang dalam hal ini telah membagi materi apa-apa saja yang seharusnya diberikan kepada anakanak khususnya dalam soal kesopan-santunan dan budi luhur ini antara lain ialah: (a) kesopanan jiwa, dan (b) kesopanan bermasyarakat yang meliputi; kesopanan makan, kesopanan berpakaian, kesopanan berbicara, kesopanan berkawan, kesopanan 


\section{St. Rodliyah}

tingkah laku, dan kesopanan kepada orang tua, guru dan lainlain.

Selain materi pendidikan akhlak materi keagamaan pada lembaga Taman Kanak-Kanak (TK) diberikan juga materi akidah dan syariah (fiqh/ibadah). Ketiga materi tersebut diberikan secara terkait, karena ketiganya saling ada keterkaitan antara yang satu dengan yang lainnya. Misalnya akidah, pengenalan terhadap Allah swt, melalui pemberian materi rukun iman ada 6 secara utuh. Hal tersebut akan dicerna dan difahami oleh anak sebagai konsep dan teori yang benar-benar dihayati dan kemudian diamalkan dalam perilaku sehari-hari. Syariah (fiqh/ibadah), materi seprti rukun Islam ada 5 (lima) itu tidak hanya cukup dimengerti, difahami sebagai konsep dan teori, tetapi yang paling penting adalah menghayati dan mau mengamalkan ibadah tersebut dalam perilaku keseharian. Begitu juga materi akhlak, tentang sopan santun dalam bertutur kata, berperilaku, dan berbuat, itu juga harus difahami dan laksanakan dalam kehidupan. Sehingga kalau sudah mampu mengamalkan dalam kehidupan sehari-hari, maka dia akan menjadi hamba Allah yang benar-benar sudah amal ma'ruf nahi munkar dan insya Allah mendapatkan ridlo dari Allah swt.

Melalui penanaman nilainilai dasar agama Islam yang kokoh di masa kanak-kanak, di harapkan nantinya anak memiliki landasan hidup yang mampu menuntun mereka menuju kejalan yang benar dan diridhoi oleh Allah swt., yaitu kehidupan yang barokah dan bermanfaat baik bagi dirinya sendiri, masyarakat, agama, maupun bangsanya. Berangkat dari statment tersebut, maka penelitian ini mengandung makna sebagai berikut:

a. Nilai-nilai dasar agama Islam sangat penting untuk 
ditanamkan pada anak sejak usia dini (kanak-kanak), karena secara psikososiokultural edukatif masa usia dini/kanakkanak dipandang sebagai masa kritis bagi rangsanganrangsangan yang masuk pada motorik, akal-fikir, emosional, dan sosial anak. Pada saat itu stimulus yang masuk mempunyai implikasi (dampak) yang lama terhadap pertumbuhan dan perkembangan diri seseorang secara optimal.

b. Dalam perspektif Islam anak dipandang sebagai aset yang sangat berharga untuk investasi masa depan baik duniawi maupun ukhrowi. Aset ini harus diinvestasikan semaksimal mungkin agar kelak si anak menjadi manusia yang paripurna (insan kamil). c. Kejayaan Islam dan kejayaan generasi muslim yang akan datang terletak pada tangantangan kita (orang tua dan para pendidik khususnya guru TK) yang kini menyusun pondasi dasarnya dengan segala macam kurikulum kegamaan, model pembelajaran, dan metode pembelajaran dalam menanamkan nilai-nilai dasar agama Islam agar kelak anak menjadi manusia yang bertaqwa dan memiliki iman yang kokoh, serta benar-benar menjadi manusia yang berkualitas serta unggul khususnya unggul dihadapan Allah swt.

3. Analisa Implikasi penanaman nilai-nilai dasar agama Islam terhadap perilaku anak TK "Al-Amien" Jember 


\section{St. Rodliyah}

baik di rumah maupun di sekolah.

Implikasi penanaman nilainilai dasar agama Islam terhadap perilaku anak TK "Al-Amien" Jember baik di rumah maupun di sekolah, menunjukkan adanya implikasi yang signifikan. Hal tersebut dibuktikan di sekolah dengan diberikannya/ ditanamkannya pendidikan Islam di masa kanak-kanak itu akan lebih meresap dan berhasil serta akan menjadi dasar dalam kehidupan selanjutnya. Sebab hal yang pertama kali masuk ke dalam jiwa anak itu akan merupakan landasan bagi kemampuan dan keahliannya serta perkembangan dia selanjutnya akan banyak terpengaruh pada landasan tersebut.

Hal tersebut diperkuat oleh pendapat Syaikh Ibnu Jauzi "AtTibbur Rukhani” juga mengatakan: bahwa " sebaikbaiknya memberikan bimbingan adalah pada waktu kecil, jika anak itu sudah besar dia sudah mempunyai suatu macam tabiat dimana dia akan berkembang menuruti tabiat itu, dan jika sudah biasa dalam keadaan demikian dia akan sukar diubah".

Karena demikian, maka dalam waktu yang begitu penting memberikan bekas bagi tiap-tiap jiwa manusia (waktu kanak-kanak) itu, janganlah sampai kita lewatkan kesempatan untuk menuangkan jiwa ke-Islaman atau nilai-nilai dasar agama Islam padanya, sebab itu waktu yang begitu baik untuk mengisikan jiwa ke-Islaman tersebut tidak dapat dinanti kembali di dalam kesempatan lain.

Prof. Muhyi Hilal Sarhan mengatakan dalam suatu uraiannya di dalam at-Tarbiyah alIslamiyah No. 12-1966 (terbit di bagdad) bahwa: "Agma Islam memberikan perhatian besar terhadap anak-anak dalam periode ini (umur 1-5 tahun) mengingat akibatnya atau implikasinya yang besar dalam kehidupan kanak- 
kanak baik dari segi pendidikan, bimbingan serta perkembangan jasmaniyah maupun infialiyahnya dan pembentukan sikap serta perilaku mereka selanjutnya, sebab arah sikap dan perilaku mereka dimulai pada periode ini dan bahkan pada umur 2 (dua) tahun mereka telah meletakkan suatu dasar agama untuk perkembangan mereka selanjutnya.

$$
\text { Kadang-kadang orang }
$$
mengira, baik buruknya kanakkanak hanya tergantung pada baik buruknya pendidikan yang diberikan di tempat-tempat pendidikan resmi seperti sekolahan dan lain-lain, tetapi melupakan betapa besarnya akibat yang mempengaruhi jiwa kanakkanak dari lingkungan rumah tangga dan keluarganya. Dalam hal ini Muhammad Athiyah alAbrasyi mengemukakan dalam bukunya "at-Tarbiyatu wal-Hayat", bahwa "Kanak-kanak harus dididik dan ditempa dalam lingkungan yang baik dengan adab yang dikondisikan, agar kita dapat memberikan andil dalam perikehidupannya yang baik dan memberikan masa depannya yang bahagia.

Sedangkan perilaku di sekolah sebagaimana yang dikemukakan oleh Imam Mawardy di dalam "adabud Dun-ya wad-Dyn" bahwa untuk menjadikan anak menjadi manusia yang bermartabat dan terhormat maka pendidikan yang harus kita diberikan sebagai guru terhadap anak-anak itu adalah memberi dasar-dasar kesopanan, agar anak tersebut merasa senang melakukannya, dan dia akan tumbuh mengikuti kesopanan tersebut, sehingga nantinya jika dia sudah menjadi besar akan mudah melakukannya sebab 


\section{St. Rodliyah}

sudah biasa sejak kecilnya, seperti apa yang disabdasakan oleh Nabi saw: "Tidak ada pelajaran yang diberikan orang tua/guru kepada anak-anaknya

melebihi

memberikan didikan akhlak yang luhur dan menjaganya dari kebodohan".

Dengan demikian maka kita (orang tua/guru) yang menjadi panutan bagi anak-anak itu harus terlebih dahulu memberikan teladan yang serba baik, baik dalam kesopanan berbicara, bergaul maupun sikap-sikap lain, dalam hal demikian itu kita akan dapat mulai memasukkan secara tidak terasa kepada mereka hal-hal yang nantinya akan menjadi landasan hidup mereka selanjutnya.

\section{Simpulan}

Berdasarkan hasil data yang diperoleh di lapangan, kemudian dianalisa melalui pembahasan temuan penelitian, maka penulis menemukan kesimpulan sebagai berikut:

Model dan metode pembelajaran yang digunakan dalam penanaman nilai-nilai dasar agama Islam di TK "Al-Amien" Jember adalah beragam sesuai dengan karakteristik, kemampuan, kebutuhan, pertumbuhan, serta perkembangan anak. Untuk model pembelajaran yang digunakan dapat dikelompokkan menjadi 8 macam yaitu model pembelajaran berorientasi pada perkembangan anak, kebutuhan anak, bermain sambil belajar atau belajar seraya bermain, pendekatan tematik, kreatif dan inovatif, lingkungan kondusif, dan mengembangkan kecakapan hidup. Sedangkan metode pembelajaran yang digunakan meliputi; metode keteladanan, pembiasaan, cerita atau dongeng, nasehat, gambar/lukisan, dan bermain serta mainan. Semua model dan metode yang diterapkan oleh para guru selalu berorientasi untuk 
Vol. 13, No. 2, Oktober 2020

p-ISSN:2086 -0749

e-ISSN:2654-4784

mengembangkan perilaku dan kemampuan dasar yang ada pada anak sebaik-baiknya dan seoptimal mungkin untuk mencapai semua aspek perkembangan baik perkembangan fisik maupun psikhis (intelektual, bahasa, motorik, dan sosio emosional).

Materi yang diberikan dalam penanaman nilai-nilai dasar agama Islam di TK "Al-Amien" Jember meliputi Aqidah, syari'ah (fiqh/ibadah), dan akhlak. Misalnya akidah, pengenalan terhadap Allah swt, melalui pemberian materi rukun iman ada 6 secara utuh. Syariah (fiqh/ibadah), diberikan materi hukum halal, haram, mubah, dan rukun Islam ada 5 (lima) sekaligus dengan prakteknya, itu tidak hanya cukup dimengerti, difahami sebagai konsep dan teori, tetapi yang paling penting adalah menghayati dan mau mengamalkan dalam kehidupan sehari-hari. Begitu juga materi akhlak, tentang sopan santun dalam bertutur kata, berperilaku, dan berbuat, itu juga harus difahami dan dilaksanakan dalam kehidupan. Dengan demikian ia akan benar-benar menjadi manusia yang berkualitas dan unggul khususnya unggul dihadapan Allah swt.

Implikasi penanaman nilainilai dasar agama Islam terhadap perilaku anak baik di rumah maupun di sekolah menunjukkan adanya implikasi yang signifikan. Hal tersebut dibuktikan jika di rumah anak-anak itu mendapatkan perhatian dan didikan lingkungan yang baik dan sikap bijaksana dalam pergaulan sehari-harinya, mempunyai hubungan mesra antara si anak dengan orang tua, dan saudaranya, begitu juga di sekolah dengan ditanamkannya 


\section{St. Rodliyah}

pendidikan Islam melalui pemberian materi dasar-dasar kesopanan yang berkaitan dengan akhlak yang luhur dan menjaganya dari kebodohan di masa kanakkanak itu akan lebih meresap dan berhasil serta akan menjadi dasar dalam kehidupan selanjutnya. Sebab hal yang pertama kali masuk ke dalam jiwa anak itu akan merupakan landasan bagi kemampuan dan keahliannya serta perkembangan dia selanjutnya akan banyak terpengaruh pada landasan tersebut. Dan hal tersebut memotivasi anak menjadi manusia yang bermartabat dan terhormat.

\section{Daftar Pustaka}

Azwar, Saifuddin, 1998, Sikap Manusia: Teori dan Pengukurannya, Yogyakarta: Pustaka Pelajar.

Arikunto, Suharsimi, 1993, Prosedur Penelitian: Suatu Pendekatan Praktek, Jakarta; PT. Rineka Cipta.

Bogdan, R.C., \& Taylor, S.J., 1975. Introduction To Qualitative Re- search Methods : A Phenomenological Approach The Social Sciences, New York : Jhon Wiley \& Sons.

Bogdan.R.C., \& Biklen, 1982. Qualitative Research For Educational An Introduction To Theory And Method, Toronto: Allyn Bacon Inc.

Depdiknas, 2003, Kurikulum 2004 Standar Kompetensi Pendidikan anak Usia Dini: Taman Kanak-Kanak dan Raudhatul Athfal, Jakarta.

Djazuli, 2004, Sosialisai Nilai-Nilai Agama Pada Anak Dalam Keluarga Muslim, Jurnal, ElHarakah, Wacana Kependidikan, Keagamaan dan Kebudayaan, Malang: UIN.

Flower, 2006, Bolebkah Anak Usia Dini Belajar Beraksara?, Sumber: http:/www.suara pembaharuan. Com/News/2006/05/17/I ndex.html.

Ary H, Gunawan. 2000. Sosiologi Pendidikan. Jakarta : PT. Rineka Cipta

Hasan, M, Tholhah, 2003, Islam Dan Masalab Sumber Daya Manusia, Jakarta: Lantabora Press 
Hikmawati, Ima., 2006, Mendidik Anak Sejak Usia Dini, forum Guru-Pikiran Rakyat-Edisi Online-www.Pikiran-

Rakyat.com.

Miles, Manthew.B and Huberman, A.M, Qualitative Data Analysis, A.Cource Book Of New Method Berverly Hills : sage publication Inc. 1992.

Moleong. L.J..2000, Metodologi Penelitian Kualitatif, Bandung: Remaja Rosdakarya.

Muamar, Aam, 2006, Optimalisasi Pendidikan Agama, http://www.Suara Pembaharuan.

Com/News/2006/05/17/I ndex.html..

Tafsir, Ahmad, 1994, Ilmu Pendidikan Dalam Perspektif Islam, Bandung: Rosdakarya.

Uhbiyati, Nur, 1998, Ilmu Pendidikan Islam, Bandung: CV. Pustaka Setia.

Walgito, Bimo, 2003, Psikologi Sosial: suatu Pengantar, Yogyakarta: PT. Remaja Rosdakarya. 